\title{
A new subfamily of Mesozoic Hylicellidae (Homoptera: Cicadomorpha)
}

\section{Новое подсемейство мезозойских Hylicellidae (Homoptera: Cicadomorpha)}

\author{
Dmitry E. Shcherbakov \\ Амитрий Е. Щербаков
}

Borissiak Paleontological Institute, Russian Academy of Sciences, Profsoyuznaya Str., 123, Moscow 117647 Russia; dshh@narod.ru
Палеонтологический институт им. А.А. Борисяка РАН, Профсоюзная ул., 123, Москва 117647 Россия.

KEY WORDS: Homoptera, Cicadomorpha, Hylicellidae, Membracoidea, Archijassidae, fossil, phylogeny, venation, Mesozoic, Triassic, Jurassic, Cretaceous.

КЛЮЧЕВЫЕ СЛОВА: Ноmoptera, Cicadomorpha, Hylicellidae, Membracoidea, Archijassidae, ископаемые, филогения, жилкование, мезозой, триас, юра, мел.

ABSTRACT. New monobasic genera Conjucella selene gen. et sp.n. (Lower Cretaceous of Transbaikalia) and Cinemala contrasta gen. et sp.n. (Middle or Upper Jurassic of Mongolia) are placed in the new subfamily Conjucellinae subfam.n. (Hylicellidae) along with Homopterites Handlirsch, 1906 from the uppermost Triassic of England and Liassocercopis Ansorge, 1996 from the Lower Jurassic of Germany. Purbecellus gen.n. is proposed for Cicadellium psocus Westwood, 1854 (= Cercopidium telesphorus Westwood, 1854): Purbecellus psocus (Westwood, 1854), comb.n. (Archijassidae: Karajassinae).

PЕЗЮМЕ. Новые монотипные роды Conjucella selene gen. et sp.n. (нижний мел Забайкалья) и Cinemala contrasta gen. et sp.n. (средняя или верхняя юра Монголии) отнесены к новому подсемейству Conjucellinae subfam.n. (Hylicellidae), наряду с Homopterites Handlirsch, 1906 из верхов триаса Англии и Liassocercopis Ansorge, 1996 из нижней юры Германии. Для Cicadellium psocus Westwood, 1854 (= Cercopidium telesphorus Westwood, 1854) установлен новый род Purbecellus gen.n.: Purbecellus psocus (Westwood, 1854), comb.n. (Archijassidae: Karajassinae).

\section{Introduction}

The family Hylicellidae was established for a Triassic genus [Evans, 1956]. Later a second subfamily was added, Vietocyclinae (Jurassic - Lower Cretaceous) [Shcherbakov, 1988]. This family and a related Triassic one, Chiliocyclidae, were separated into the superfamily Hylicelloidea, considered ancestral to all three extant superfamilies of Cicadomorpha (Membracoidea, Cercopoidea, and Cicadoidea) [Shcherbakov, 1996]. Yet another Triassic family, Mesojabloniidae was recently transferred to Hylicelloidea [Shcherbakov, 2011].
The family Ligavenidae (Lower Cretaceous) and the superfamily Ligavenoidea [Hamilton, 1992] were synonymized under Hylicellidae and Hylicelloidea, respectively [Shcherbakov, 1996]. The family Archijassidae [Becker-Midgisova, 1962], formerly placed in Hylicelloidea as a subfamily of Hylicellidae [Shcherbakov, 1992], was removed to Membracoidea [Ansorge, 1996] and expanded to include Karajassinae and Dellasharinae [Shcherbakov, 2012].

Two peculiar new genera described herein, Jurassic Cinemala gen.n. and Early Cretaceous Conjucella gen.n., can be linked to the more typical hylicellids via the more primitive latest Triassic Homopterites Handlirsch, 1906 and Early Jurassic Liassocercopis Ansorge, 1996. All the four genera are classified in a new subfamily of Hylicellidae, Conjucellinae subfam.n.

The vein nomenclature is after Shcherbakov [2012]. The specimens described below are preserved at the Borissiak Paleontological Institute RAS, Moscow (PIN). The numbers of specimens represented with part and counterpart are marked with " \pm ”. Photographs were taken using a Leica M165C stereomicroscope and Leica DFC425 camera. Conjucella selene sp.n. was imaged without coating with backscattered electron (BSE) detector of a Tescan Vega XMU scanning electron microscope.

\section{Taxonomy}

Superfamily Hylicelloidea Evans, 1956

Family Hylicellidae Evans, 1956

Subfamily Conjucellinae Shcherbakov, subfam.n.

TYPE GENUS. Conjucella gen.n.

DIAGNOSIS. Medium-sized. Tegmen elongate. Precostal carina broader than hypocostal one. bSc separated from $\mathrm{R}+\mathrm{M}$. Basal cell long, narrow (especially near base), pointed at apex; $\mathrm{CuA}$ base much more raised 
than $\mathrm{R}+\mathrm{M}$; CuA elbowed at apex of basal cell; arcular fold along base of $\mathrm{CuA}$ stem absent. Usually stigmal cell narrow and dSc short. RP strongly arcuate basally, or originating early, or fused to MA for a distance; radial space at RP origin broader than medial one. RA simple (rarely forked); MA simple, MP forked or simple, CuA1 simple; 5-7 apical cells. 1A markedly converging to Pcu about midlength of clavus and/or connected to it by crossvein. Margin often 'zebroid' (pale with regular dark patches, including those at veins' apices).

COMPOSITION. Type genus from the Lower Cretaceous of Transbaikalia, Cinemala gen.n. from the Middle or Upper Jurassic of Mongolia, Homopterites Handlirsch, 1906 (H. anglicus Handlirsch, 1906) from the uppermost Triassic of England, and Liassocercopis Ansorge, 1996 (L. schnicki Ansorge, 1996) from the Lower Jurassic of Germany.

COMPARISON. Distinct from other Hylicellidae in the poor vein branching, absence of arcular fold, trait to align arculus with $\mathrm{CuA}$ base, and medial cell small and/ or contiguous with radial cell and/or $\mathrm{CuA}$ fork in the tegmen.

REMARKS. Some traits of Conjucellinae are shared with Membracoidea, e.g. the contiguous subapical cells and marginal appendix cut off by the straight ambient vein in Conjucella gen.n., and the narrow costal space in Liassocercopis. However, conjucellines retain the structure of the basal cell characteristic of Hylicellidae and are not closely related to Archijassidae — the doubtless early membracoids.

\section{Key to genera of Conjucellinae (TEgmen)}

1 Two subequal, contiguous subapical cells (medial cell broadly contiguous with both radial cell and $\mathrm{CuA}$ fork). Marginal appendix cut off by straight section of ambient vein and reaching distad of $\mathrm{CuAl}$ apex. $\mathrm{R}$ and $\mathrm{M}$ forming stalk beyond basal cell ................. Conjucella gen.n.

- Two unequal, isolated subapical cells (shorter medial cell at most touching radial cell and/or CuA fork). No such appendix

2 Radial and medial cells long (R stem much shorter than basal cell; medial cell longer than $\mathrm{CuA}$ fork). $\mathrm{CuA}$ stem arcuate. MP simple. Stigmal cell long

Cinemala gen.n.

- Radial and medial cells shorter (R stem nearly as long as basal cell; medial cell shorter than $\mathrm{CuA}$ fork). $\mathrm{CuA}$ stem bisinuate. MP forked

3 Costal space much widened basally, costal margin more deeply arched there. Stigmal cell short triangular .......... Homopterites Handlirsch, 1906

- Costal space less widened basally; costal margin shallowly arched or nearly straight before midlength Liassocercopis Ansorge, 1996

Conjucella Shcherbakov, gen.n.

TYPE SPECIES. Conjucella selene sp.n.

DIAGNOSIS. Tegmen: costal margin deeply arched near base; two subequal, contiguous subapical cells; $\mathrm{R}+\mathrm{M}$ stalk distinct; MP simple; appendix well-devel- oped; fuscous with oblong pale spots and zebroid margin.

COMPOSITION. Monobasic.

ETYMOLOGY. From Latin conjugare (to yoke together) and cella (small room); gender feminine.

\section{Conjucella selene Shcherbakov, sp.n.} Figs 1-3.

MATERIAL. Holotype right tegmen PIN 3064/4634 (bed 31); paratypes: female PIN 4210/1013 (bed 15) and left tegmen PIN 4210/1014 \pm (bed 22), both poorly preserved; Baissa, upper reaches of Vitim R., Buryatia, Russia; Zaza Formation, Lower Cretaceous.

DESCRIPTION (Figs 1-3). Tegmen $12.8 \mathrm{~mm}$ long and $3.9 \mathrm{~mm}$ wide (holotype), elongate (3.3:1), broadest before apex of basal cell, costal margin deeply arched here and straight about RP origin; precostal carina broad up to RP origin, continued beyond $\mathrm{dSc}$. R+M stalk beyond basal cell; medial space narrowest before midlength. $\mathrm{R}$ forked just before $\mathrm{M}$ fork. Medial cell broadly contiguous with both radial cell and $\mathrm{CuA}$ fork; im short or replaced with $\mathrm{MA}+(\mathrm{MP}+\mathrm{CuA} 1)$ anastomosis, $\mathrm{MP}+\mathrm{CuA} 1$ forked or simple. $\mathrm{CuA}$ base, long arculus, and R stem aligned and markedly raised. Moderately wide appendix (adjacent to $\mathrm{CuA}$ fork and cut off by straight ambient vein) continued with very narrow marginal membrane around tegmen apex. Unevenly infuscate (no contrasting bands), except for oblong pale spots at base of $\mathrm{CuA}$ stem and between $\mathrm{R}$ and $\mathrm{M}$ forks; margin zebroid. Unevenly covered with dark punctures (most densely around spots, subapically along veins only), in some areas nearly foveolate. Veins within spots (base of $\mathrm{CuA}$ stem, most of RP+MA) weak. Paratypes smaller (tegmen 10.3-11.7 mm long), with anastomosis instead $\mathrm{im}$.

ETYMOLOGY. Greek selene (Moon).

\section{Cinemala Shcherbakov, gen.n.}

TYPE SPECIES. Cinemala contrasta sp.n.

DIAGNOSIS. Tegmen: costal margin moderately arched; two unequal, isolated subapical cells; MP simple; stigmal cell long; RA forked; appendix absent; dark with transverse pale bands.

COMPOSITION. Monobasic.

ETYMOLOGY. From French cinéma (shortened from cinématographe, from Greek kinema, movement) and Latin ala (wing); gender feminine.

\section{Cinemala contrasta Shcherbakov, sp.n.} Figs 4-5.

MATERIAL. Holotype left tegmen PIN 3791/2134(2177)t; Bakhar (=Bahar), outcrop 275/1, $12 \mathrm{~km} \mathrm{NE}$ of Tsetsen-Ula Mt., Bayankhongor Aimag, Central Mongolia; Togo-Khuduk Member, Bakhar Group, Middle or possibly Upper Jurassic.

DESCRIPTION (Figs 4-5). Tegmen $8.3 \mathrm{~mm}$ long and $2.5 \mathrm{~mm}$ wide, elongate (3.3:1), broadest in middle third, costal margin more arched before apex of basal cell than about RP origin; precostal carina narrow ex- 

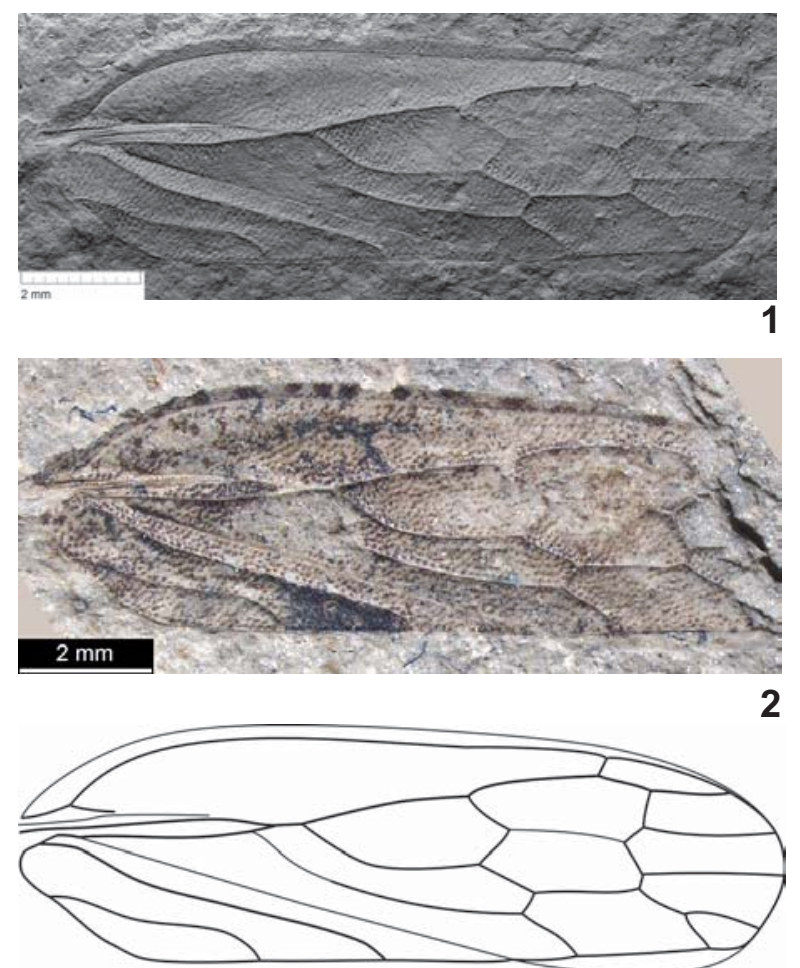

3

Figs 1-3. Conjucella selene sp.n., Baissa, Lower Cretaceous, holotype PIN 3064/4634, tegmen: 1 - positive impression (SEM micrograph, BSE); 2 - negative impression (mirror image); 3 venation.

Рис. 1-3. Conjucella selene sp.n., Байса, нижний мел, голотип ПИН 3064/4634, переднее крыло: 1 - прямой отпечаток (СЭМ микрофотография, ОЭ); 2 - обратный отпечаток (перевернуто зеркально); 3 - жилкование.

cept near base. $\mathrm{R}$ and $\mathrm{M}$ forming at most very short, indistinct stalk beyond basal cell; medial space narrowest at base. $\mathrm{R}$ forked much before $\mathrm{M}$ fork. Medial cell separated from both radial cell and $\mathrm{CuA}$ fork; im long; both MP and $\mathrm{CuAl}$ simple. $\mathrm{CuA}$ base and $\mathrm{R}$ stem separated by zone with weak veins and not forming continuous raised line; arculus short. No appendix. Dark with contrasting pale: apex (except for dark marginal patch posterior to MP) and two broad transverse bands (subbasal one incomplete, being reduced in clavus); margin mostly darkened, not zebroid. Densely punctate in dark parts of clavus and costal space, punctate only along veins in other dark zones. Veins within pale bands (especially apex of basal cell, base of $\mathrm{CuA}$ stem, M before fork) weak.

ETYMOLOGY. From Latin contrastare (to withstand).

Superfamily Membracoidea Rafinesque, 1815

Family Archijassidae Becker-Migdisova, 1962

Subfamily Karajassinae Shcherbakov, 1992

Recently, I synonymized Cercopidium telesphorus Westwood, 1854 (based on a tegmen) under Cicadelli-

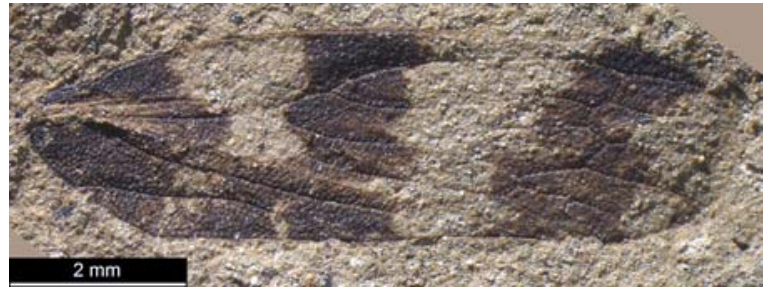

4

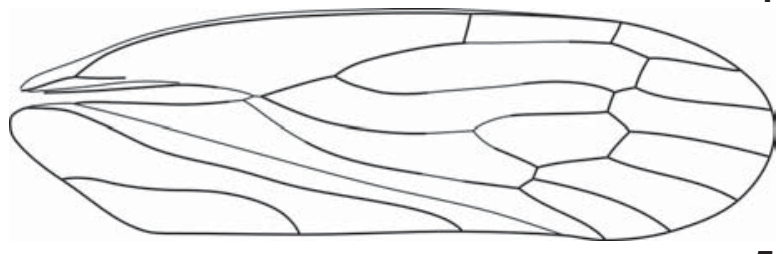

5

Figs 4-5. Cinemala contrasta sp.n., Bakhar, Middle or Upper Jurassic of Mongolia, holotype PIN 3791/2134(2177), tegmen.

Figs 4-5. Cinemala contrasta sp.n., Бахар, средняя или верхняя юра Монголии, голотип ПИН 3791/2134(2177), переднее крыло.

um psocus Westwood, 1854 (based on a hindwing; both from Purbeck Beds of England), designated C. psocus as the type species of the genus Cicadellium Westwood, 1854 , assigned the latter to Karajassinae, and transferred the second species of that genus, C. dipsas Westwood, 1854 (based on a forewing) to Psocoptera [Shcherbakov, 2012]. However, I overlooked that Carpenter [1992] indicated C. dipsas as the type species of Cicadellium by subsequent designation by Handlirsch [19061908] (Handlirsch listed C. psocus under Cicadellium with a question mark). Therefore, the genus Cicadelli$u m$ with its type and only species, C. dipsas, belongs in Psocoptera, and Purbecellus gen.n. is proposed here for C. psocus.

\section{Purbecellus Shcherbakov, gen.n.}

Cicadellium sensu Shcherbakov, 2012 1854

TYPE SPECIES. Cicadellium psocus Westwood,

DIAGNOSIS. Tegmen: very elongate; proximal part punctate; single rm; $\mathrm{R}$ fork much before $\mathrm{M}$ fork; $\mathrm{R}$ and M leaving basal cell separately; arculus short; ir present; radial and medial cells long; $m c u$ replaced with rather long anastomosis; $\mathrm{CuA}$ beyond arculus arched and running close to $\mathrm{CuP}$; nodal line present. Hindwing: elongate; $m c u$ at $1 / 5$ of $\mathrm{CuA} 1 ; \mathrm{rm}$ more distal; $\mathrm{M}$ and $\mathrm{CuA}$ stems, CuP and Pcu markedly curved; Pcu proximally well separated from 1A.

COMPOSITION. Monobasic: Purbecellus psocus (Westwood, 1854) comb.n. (= Cercopidium telesphorus Westwood, 1854).

COMPARISON. In other genera of Karajassinae wings are less elongate, with less curved veins, and $\mathrm{MP}+\mathrm{CuA} 1$ is shorter in the tegmen [Shcherbakov, 2012].

ETYMOLOGY. From Purbeck Beds; gender masculine. 
ACKNOWLEDGEMENTS. I am deeply indebted to Roman Rakitov (PIN) for taking SEM micrographs and checking the English of the manuscript.

\section{References}

Ansorge J. 1996. Insekten aus dem oberen Lias von Grimmen (Vorpommern, Norddeutschland) // Neue Paläontologische Abhandlungen. Vol.2. P.1-132.

Becker-Migdisova E.E. 1962. [Some new Hemiptera and Psocoptera] // Paleontologicheskiy Zhurnal. 1962. No.1. P.89-104 [in Russian].

Carpenter F.M. 1992. Superclass Hexapoda // Treatise on Invertebrate Paleontology, Part R, Arthropoda $4(3,4)$. Boulder, Colorado, and Lawrence, Kansas: Geological Society of America and University of Kansas. 655 p.

Evans J.W. 1956. Palaeozoic and Mesozoic Hemiptera (Insecta) // Australian Journal of Zoology. Vol.4. P.165-258
Hamilton K.G.A. 1992. Lower Cretaceous Homoptera from the Koonwarra Fossil Bed in Australia, with a new superfamily and synopsis of Mesozoic Homoptera // Annals of the Entomological Society of America. Vol.85. P.423-430.

Handlirsch A. 1906-1908. Die fossile Insekten und die Phylogenie der rezenten Formen. Leipzig: Wilhelm Engelmann. $1430 \mathrm{~S}$.

Shcherbakov D.E. 1988. [New Cicadina from the Late Mesozoic of Transbaikalia] // Paleontologicheskiy Zhurnal. No.4. P.55-66 [in Russian; English translation: Paleontological Journal. 1988. Vol.22. No.4. P.52-63].

Shcherbakov D.E. 1992. The earliest leafhoppers (Hemiptera: Karajassidae n. fam.) from the Jurassic of Karatau // Neues Jahrbuch für Geologie und Paläontologie Monatshefte. P.39-51.

Shcherbakov D.E. 1996. Origin and evolution of the Auchenorrhyncha as shown by the fossil record // Schaefer C.W. (ed.). Studies on Hemipteran Phylogeny. Proceedings of Thomas Say Publications in Entomology, Entomological Society of America, Lanham, Maryland. P.31-45.

Shcherbakov D.E. 2012. More on Mesozoic Membracoidea // Russian Entomological Journal. Vol.21. No.1. P.15-22. 